\title{
Beauty Image of Indonesia and Malaysia Local Cosmetic Brand Advertising in Following K-Beauty Trend 2019/2020
}

\author{
Vania Aqmarani Sulaiman ${ }^{1 *} \quad$ Mohd Zammudin Mohd Zain ${ }^{2}$ \\ 1.Fakultas Desain Seni Kreatif, Universitas Mercu Buana, Jl. Meruya Selatan No.31, Meruya Selatan, West \\ Jakarta 11610, Indonesia \\ 2.Fakulti Teknologi Kreatif dan Warisan, Universiti Malaysia Kelantan, Karung Berkunci 36, Pangkalan Chepa \\ 16100, Kota Bharu. Kelantan
}

\begin{abstract}
Beauty products is one of the products that attract consumers' attention widely. This has encouraged the industry to grow because of the high demand. The development is related to people needs to look attractive, either because of work or the environment. The high selling value of cosmetics is due to the awareness of the importance of appearance (especially for women), so various methods are taken to get this ideal appearance either in the right way or not. Brands compete in the industry to attract customers. Brand keep up with latest trend to stay survive. Korean beauty (k-beauty) is one of the most popular trends nowadays. K-beauty trend more or less affecting local beauty industry as happened in Indonesia and Malaysia. Brand Rollover Reaction and Duck Cosmetics are example of local cosmetic brand that influenced by k-beauty trend. It can be seen both from their product and its advertisement. The motivation behind the growth of the local beauty brand industry especially in Indonesia and Malaysia has been dramatic. These two variables certainly influencing the application of k-beauty trends in both countries. This study aims to analyze how local cosmetics brand from these two countries adapting current k-beauty trend to their advertisement despite of their own culture. This study uses case study method by comparing advertisement from each local brand to find beauty image that they used. Coding and thematic analysis use as tools to categorize data, while semiotics is used to analyze the meaning of visual signs contained in the advertising. The results of this study indicate that there are differences in the adaptation methods of the two countries. Even so, local cultures are still seen in each of these advertisements. This research is expected to be beneficial for the development of similar local brands to remain alert of global trends, especially creative industries, in promoting local products.
\end{abstract}

Keywords: Beauty Image, Fashion, Beauty Advertising

DOI: $10.7176 / \mathrm{ADS} / 86-01$

Publication date:October $31^{\text {st }} 2020$

\section{Introduction}

The growth of digitalization and the influence of social media make people want to spend their income not only for their daily needs but also the needs of lifestyle and entertainment activities (quoted from markplusinsight.com, accessed on April 25, 2017, in Tantya Hapsari S, 2017). Beauty products is one of the products that attract consumers' attention widely. This has encouraged the industry to grow because of the high demand. Brands compete in the industry to attract customers. Brand keep up with latest trend to stay survive.

Korean beauty (k-beauty) is one of the most popular trends nowadays. Now, the global beauty industry is experiencing a revolution driven by South Korea (bbc.com, 2018). K-beauty trend more or less affecting local beauty industry as happened in Indonesia and Malaysia. Brand rollover Reaction and Duck Cosmetics are example of local cosmetic brand that influenced by k-beauty trend. It can be seen both from their product and its advertisement.

Previous research (Dwityanti, 2008) concluded that advertising variables have a positive influence on buying interest. Images in advertisements have the power to shape the perception of a society as far as the way they look at the world (Kuntjara, 2001). Another study indicates that body image in advertising are most effective in building the brand awareness, it is seen that most of the respondents in the sample are in favors that body image used in advertising influence them to create the need for the product in their mind (Chaubey, Sharma Jyoti, 2010). The motivation behind the growth of the local beauty brand industry especially in Indonesia and Malaysia has been dramatic. These two variables certainly influencing the application of k-beauty trends in both countries. This study aims to analyze how k-beauty trend are portrayed in beauty image of local cosmetic brand advertisement in Indonesia and Malaysia.

Wulan Purnama Sari conducted a similar study entitled " Konflik Budaya Dalam Konstruksi Kecantikan Wanita Indonesia “Analisis Semiotika Dan Marxist Iklan Pond's White Beauty Versi Gita Gutawa” (Wulan, 2015). The study explores the cultural conflict that is displayed in the advertisements Pond's White Beauty Gita version Velasquez with pretty white theme flushed like Korean. The conclusion obtained from this study is the Pond's White Beauty advertisement version of Gita Gutawa with a beautiful white blushed theme like Korean creating cultural conflict in terms of the meaning of beauty for Indonesian women. Semiotic analysis shows that 
this advertising displays stereotypes about the beauty image for Indonesian women are white skin like Korean people.

In another research conduct by Winta found that Pond's uses brand ambassadors from different countries which portrays Korean beauty skin as the new ideal standart of beauty which believed by Southeast Asian (Winta, 2017). This finding shows the inferiority of Southeast Asian women towards Korean women through the desire of Southeast Asian women to do mimicry for Korean women. It can also show that South Korea, which is also one of the Asian countries, has succeeded in developing its popular culture to be considered better from other Asian countries, including the concept of beauty.

The impact of large-scale Korean wave culture promotion on the success of their markets globally seem in quantitative research involving 602 young Malaysian consumers in the Klang Valley (Wan Roazha Wan Mat, Hyung Jun Kim, Ahmad Azaini Abdul Manaf, Grace Phang Ing, Azaze-Azizi Abdul Adis. 2019). The findings of this study confirmed the importance of roles of individual and celebrity characteristics in influencing the attitude and eventually, the intention to imitate among young consumers. Malaysian consumers have positive attitudes to use, buy, share info and even portray overt behavior implied by the hours spent on Korean wave products. Besides, this study also influences South Korean products into the global market as it would increase the promotion of the Korean goods and tourism industry. This reflected that, by highlighting every Asian culture to the audience through an attractive segment in televisions or other entertainment programs, Asian businesses would be able to influence young consumer preferences and ultimately their purchase decision.

\subsection{Semiotic}

Semiotic is one of communication science that reads signs to get meaning. A sign refers to someone, that is, creates in the mind of that person an equivalent sign or a more developed sign, the sign he creates is called an interpretant of the first sign. The sign shows something, namely the object (Nawiroh Vera, 2014). Forms of media such as newspapers, magazines, television, advertisements, and the internet are cultural products that commonly communicate messages using signs. According to Piliang, advertisement is a product of visual communication design presents graphic elements such as pictures (illustrations), letters, colors, composition, and layout (Piliang, 2004). Indirectly, advertising and its visual elements can also be considered as a language that produces meaning. According to McLuhan, the medium is the message (1964: 11), which is formed through the process of relations between the signifier and the signifier. Signifiers are messages (acoustic imagery) that are displayed in text form (both verbal and nonverbal texts) and signified are the meaning of the message. Thus, what is presented by the media is the socio-cultural reality that is constructed and communicated through messages. Furthermore, John Fiske emphasized that the media not only presents certain representations of reality but also the media influence and produce the reality that they provide (2004: 1).

In interpreting reality, humans utilize two elements, Ferdinand de Saussure calls it signfiant (sign) and signefié (sign). Saussure uses the terms signifiant (signifier) in terms of the shape of the sign, and signifié (signified) in terms of its meaning. Thus, all that is present in reality is seen as a sign that is understood or interpreted through a process of significance between the sign (reality) and the sign (specific meaning given to reality). Roland Barthes sees reality as a sign that is built through two levels of meaning, namely denotation, and connotation. In his theory denotation as the first stage of signification system (primary system), the meaning is generally accepted in the basic conventions of society. Whereas connotation is a new meaning given by the user of sign that can be from the ideological and socio-cultural background of a society or based on conventions, that exist in society (Barthes, 1977: 89-90). In the development of the Barthes sign system, the meaning of connotations based on cultural or ideological views by society can become a myth, namely a way of thinking of a culture or an ideology towards a reality. For Barthes, myth is the ideological implications of what seems natural, 'myth' means a delusion to be exposed (Culler, 2001: 2). Myth is a way of conceptualizing or naturalizing certain realities in the sign user community (Fiske, 2004: 121).

\subsection{Korean Beauty}

Looking from its history like most countries in East Asia, were influenced by western countries during the World War II. From the 1920s to the end of World War II, both Japanese men and women began to have a strong desire to appear more western in regard to clothing, hair, and appearance, all of which was viewed as more modern and desirable (Choi Eunji, 2018). Those ideas were brought to Korea through Japanese colonization during the World War II and has largely influenced Korean people's idea of beauty. During its development, Korean beauty also produced several trends such as make-up style, ideal body shape, dress style that was considered fashionable as they always tried to tolerate through the Korean wave culture. K-drama, K-idol such as the boy band or girl band, and K-beauty which is specifically discussing beauty trends is an example of Korean wave culture. Some latest $\mathrm{k}$-beauties that have been summarized from various world fashion media are as follows: 
Tabel 1. K-beauty trend 2019/2020

\begin{tabular}{|c|c|}
\hline Name of trend & escription \\
\hline $\begin{array}{ll}\text { The "glass } \\
\text { skin" } \\
\text { up }\end{array}$ & $\begin{array}{l}\text { Dewy finishes come in and out of fashion, but this particular iteration is influenced by Korean } \\
\text { beauty. The trend has been building in Korea since 2013, said Charlotte Cho, the founder of the } \\
\text { K-beauty retailer Soko Glam and the skin-care line Then I Met You. In Korea, "glass skin," or } \\
\text { "honey skin," came to describe a "clear, poreless, translucent complexion," she said. It has now } \\
\text { arrived in the West, she said, via viral Instagram looks (nytimes.com, 2019). }\end{array}$ \\
\hline Lip gradient & $\begin{array}{l}\text { One of Korean most know lip make-up style is lip gradient. It shows in so many make-up brand } \\
\text { advertisement, Korean idol make-up style, and Korean drama make-up style. Gradient lips are } \\
\text { meant to give that "just bitten" effect, with a darker color concentrated in the center of the lips, } \\
\text { then fading out at the edges, or blending into a different color. In Korea, the look is said to give } \\
\text { a more youthful and innocent appearance (Sabrina Tiong, 2015). This make-up style has } \\
\text { existed even since } 2008 \text { and is still the most popular Korean make-up style to this day. This is } \\
\text { evident from the many Korean make-up brands that use this style in their product promotions. }\end{array}$ \\
\hline Glittery eyes & $\begin{array}{l}\text { nother popular Korean make-up trend that going global is glittery eyes. Daily vanity } \\
\text { ingapore said that Korean glittery eyes will still stand out in } 2020 \text { (Vivian Yeong, 2019). the } \\
\text { littery eyes style carried by Korean make-up looks natural with fine glitter particles but still } \\
\text { eems glossy on the lid. }\end{array}$ \\
\hline $\begin{array}{lr} & \text { "Thin } \\
\text { and } & \text { Matte- } \\
\text { Hot } & \text { Pink } \\
\text { Lips" } & \end{array}$ & $\begin{array}{l}\text { These days, people in Korea are moving away from flashy false lashes and toward a low-key } \\
\text { lash look. The result is sparser and separated than the lush lashes often seen Stateside, but the } \\
\text { Korean trend still gives eyes a widening effect (Albeman Devon,2019). } \\
\text { Furthermore, in the allure magazine article explained that although glossy lips are trending in } \\
\text { America, matte is quite a big trend at the moment in Korea. Natalie Lee, a manager at } \\
\text { Jennyhouse said that in the past, people in Korea didn't focus on bigger, voluminous lips, but } \\
\text { lately, the fuller look has been more desired than ever before. In addition to getting fillers to } \\
\text { achieve it, Lee said they have been drawing attention to their lips with velvety matte lipstick in } \\
\text { a fun hot-pink hue (Albeman Devon,2019). }\end{array}$ \\
\hline $\begin{array}{l}\text { Fashion and } \\
\text { Accessorize }\end{array}$ & $\begin{array}{l}\text { Monica Kim, Vogue.com's fashion news editor said that the fashion in Seoul moves fast and is } \\
\text { incredibly trend-driven. } \\
\text { Jung Ku-ho founder of Seoul Fashion Week said that Seoul's fashion scene is very much } \\
\text { involved with street culture; the city is not really into high-end fashion, but more so into } \\
\text { affordable streetwear that is influenced by K-pop stars and K-entertainment (scmp.com, 2017) } \\
\text { Korean tend to accessorize with almost everything they wear. One of the essentials is to keep } \\
\text { hair clips. It is very common to see K-stars accessorizing their outfit with a nice hair clip } \\
\text { (Mindy Wright, 2019). }\end{array}$ \\
\hline
\end{tabular}

\section{Research Method}

This study uses descriptive qualitative methods by taking and dissecting data samples to identify the visual meaning of the beauty image of local cosmetic brand advertisement in the following K-beauty trend 2019/2020.

\subsection{Research Approach}

The approach used in research is a case study approach. Quoted by Guba \& Lincoln, case study is a study that examines a complete and intensive aspect, issues, and possibly events about the geographical background repeatedly. Cases are not only limited to people or organizations, but also the limits of systems, programs, responsibilities, collections, or populations. According to Yin the types of case studies are divided into three namely exploratory, descriptive, and explanatory case studies (Subadi, 2006). This research itself focuses on the type of explanatory case studies because the direction of research that will aim to describe the analysis so that later can conclude a way or method. The object of research taken as a case study sample in this study is the local cosmetic brand advertisement from Indonesia and Malaysia. The sample is chosen based on the popularity of the brand based on local beauty award in each country (the year between late 2018 until late 2019) to fit the Kbeauty trend of 2019/2010. While the data analysis technique used in this study is semiotics theory as a data analysis tool. The reason semiotics theory was chosen as the method of analysis in this research is to find the meaning of visual signs contained in the research object so that later the meaning is expected to be a guide to mapping the methods used by the research object as a way in adapting the K-beauty trend 2019/2020.

To be able to facilitate the discovery of the meaning of visual signs in research objects, the researcher will categorize the visual signs on the beauty image first using thematic analysis theory. Thematic analysis is a method of analyzing qualitative data (Jack Caulfield, 2019). Thematic analysis is the process of identifying patterns or themes within qualitative data. The goal of a thematic analysis is to identify themes, for example patterns in the data that are important or interesting, and use these themes to address the research or say 
something about an issue. Meaning-making of the visual data is not the same as meaning-making of language (Hooper-Greenhill, 2000; Belova, 2006). One of tools that can help categorizing data in visual analysis is coding. Generate initial codes to limit the problem by categorizing the data. Coding is an interpretive technique that organizes the data and provide a means to introduce the interpretations of the data into certain qualitative methods (Denzin and Lincoln, 2005; Marshall and Rossman, 1998).

The categorization of visual signs on the beauty image in this research is theme of external beauty which are face and body. While to analyze the ad, the researcher divides the elements into several points below:

1. The Mood

2. The Design

3. The Context and Content

4. Visual sign of beauty related to face: The race of people in the advertisement and the style of makeup and hair in the advertisement.

5. Visual sign of beauty related to body: Body shape of people in the advertisement and the style of fashion that worn in the advertisement.

\subsection{Research Stage}

The target of this research is to find the identification of signs and meanings of signs contained in the object of research related to the K-beauty trend 2019/2020. Indicators of the success of this study include the mapping of the adaptation methods that they used in their advertisement related to the Korean beauty trend 2019/2020.

The following are the stages of research that will be done during the research process:

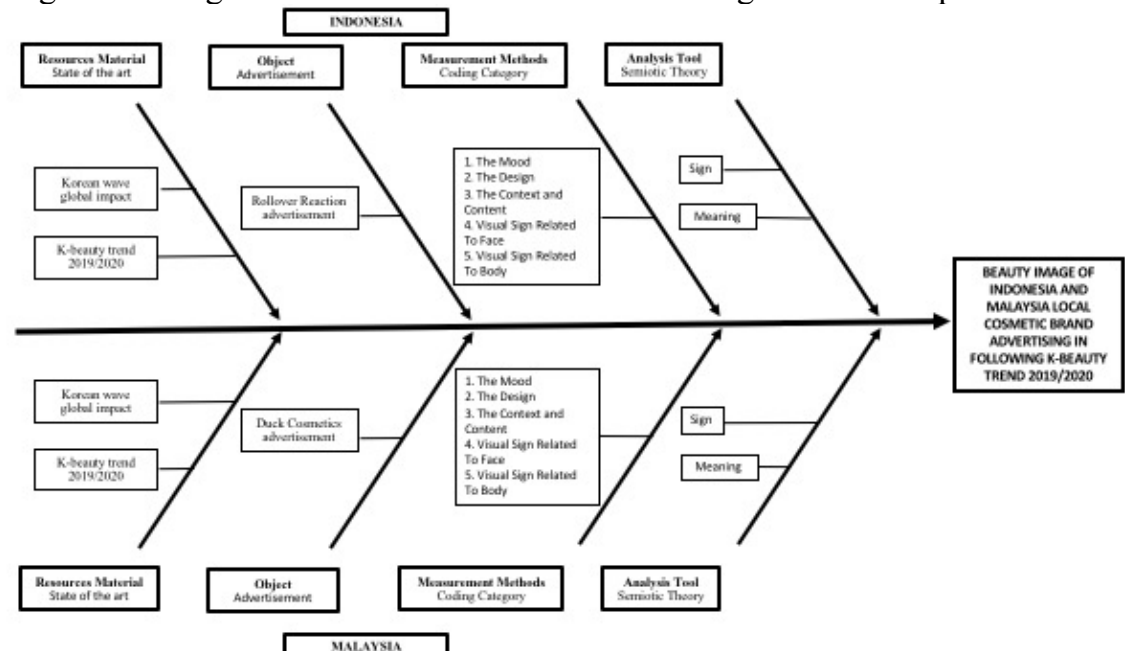

Figure 1. Research Method

Ads taken are advertisements published in the range of 2019 and early 2020. To get a clearer picture, the number of ads that will be taken as a sample is 3 ads from each country as follow:

1. Indonesian Brand Advertisements (Ad 1, Ad 2, and Ad 3 left to right)

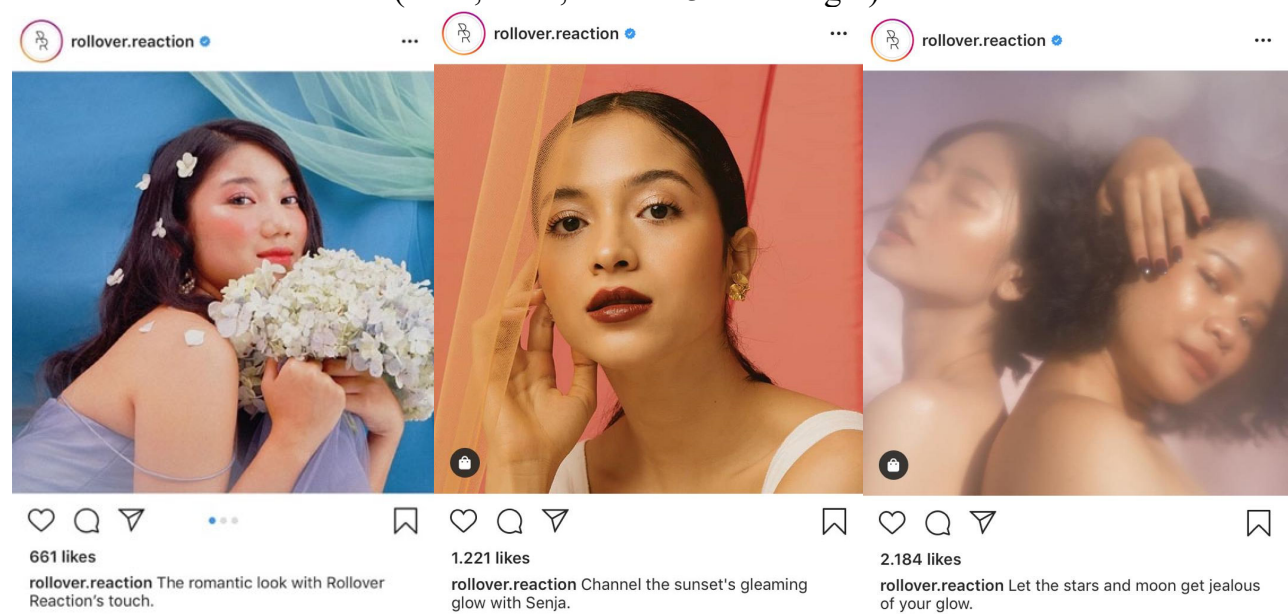

Figure 2. Rollover Reaction Ads

Here is a table containing advertisements and an explanation of the visual elements in the beauty image contained in each advertisement: 
Table 2. Coding of Visual Element in Indonesia Advertisement

\begin{tabular}{|c|c|c|c|c|c|}
\hline No. & Criteria & Description & Ad 1 & Ad 2 & Ad 3 \\
\hline 1. & The Mood & $\begin{array}{l}\text { Feelings that stimulates } \\
\text { the audience }\end{array}$ & $\begin{array}{l}\text { Youth and } \\
\text { romantic }\end{array}$ & $\begin{array}{l}\text { Elegant and } \\
\text { romantic }\end{array}$ & Dreamy \\
\hline \multirow{2}{*}{2.} & \multirow{2}{*}{$\begin{array}{l}\text { The } \\
\text { Design }\end{array}$} & $\begin{array}{l}\text { 1. Style of } \\
\text { Photograph }\end{array}$ & Close up portrait. & $\begin{array}{l}\text { Close up } \\
\text { portrait. }\end{array}$ & Close up portrait. \\
\hline & & $\begin{array}{l}\text { 2. Colour scheme of } \\
\text { photograph }\end{array}$ & $\begin{array}{l}\text { Pastel colour } \\
\text { tone. }\end{array}$ & $\begin{array}{l}\text { Warm colour } \\
\text { tone. }\end{array}$ & Retro colour tone. \\
\hline \multirow[b]{2}{*}{3.} & \multirow[b]{2}{*}{$\begin{array}{l}\text { The } \\
\text { Context } \\
\text { and } \\
\text { Content }\end{array}$} & $\begin{array}{l}\text { 1. Language use in } \\
\text { the advertisement }\end{array}$ & $\begin{array}{l}\text { English } \\
\text { language. }\end{array}$ & $\begin{array}{l}\text { English } \\
\text { language. }\end{array}$ & English language. \\
\hline & & 2. Caption purpose & $\begin{array}{l}\text { Persuade people } \\
\text { to use Rollover } \\
\text { Reaction product } \\
\text { to get the look. }\end{array}$ & $\begin{array}{l}\text { Informing } \\
\text { people of } \\
\text { perfect timing to } \\
\text { use the product. }\end{array}$ & $\begin{array}{l}\text { Convince people } \\
\text { that the product } \\
\text { can make their } \\
\text { face glow like a } \\
\text { star. }\end{array}$ \\
\hline \multirow[t]{2}{*}{4.} & \multirow{2}{*}{$\begin{array}{l}\text { The Visual } \\
\text { Sign of } \\
\text { Beauty } \\
\text { (face) }\end{array}$} & $\begin{array}{l}\text { 1. The race of people } \\
\text { in the } \\
\text { advertisement }\end{array}$ & $\begin{array}{l}\text { Indonesian with } \\
\text { oriental type of } \\
\text { face. }\end{array}$ & Indonesian. & $\begin{array}{l}\text { Indonesian with } \\
\text { oriental type of } \\
\text { face and East } \\
\text { Indonesian type } \\
\text { of face. }\end{array}$ \\
\hline & & $\begin{array}{l}\text { 2. Style of makeup } \\
\text { and hair }\end{array}$ & $\begin{array}{l}\text { Romantic style } \\
\text { makeup and hair. }\end{array}$ & $\begin{array}{l}\text { Chic style of } \\
\text { makeup and } \\
\text { hair. }\end{array}$ & $\begin{array}{l}\text { Nude style of } \\
\text { makeup and hair. }\end{array}$ \\
\hline \multirow[b]{2}{*}{5.} & \multirow{2}{*}{$\begin{array}{l}\text { The Visual } \\
\text { Sign of } \\
\text { Beauty } \\
\text { (body) }\end{array}$} & $\begin{array}{l}\text { 1. Body shape of } \\
\text { people in the } \\
\text { advertisement }\end{array}$ & Not available. & Not available. & Not available. \\
\hline & & $\begin{array}{l}\text { 2. Fashion and } \\
\text { accessories }\end{array}$ & $\begin{array}{l}\text { Lilac gown and } \\
\text { gold drop } \\
\text { statement } \\
\text { earrings. }\end{array}$ & $\begin{array}{l}\text { White tank top } \\
\text { with gold stud } \\
\text { earring. }\end{array}$ & Not available. \\
\hline
\end{tabular}

2. Malaysian Brand Advertisement (Ad 1, Ad 2, and Ad 3 left to right)

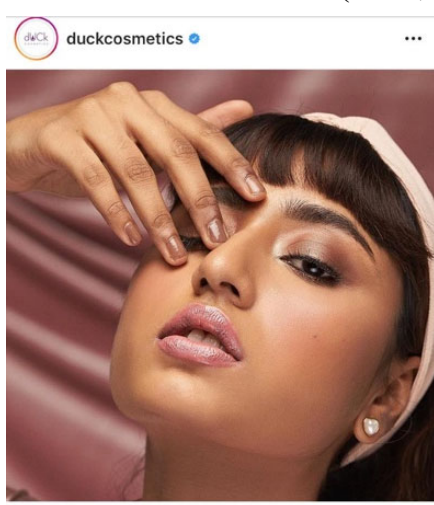

$\bigcirc \bigcirc \nabla$

435 likes

duckcosmetics You can never go wrong with a sweet pink. Matte Love in Pink Crush is the show-stopper рuсксовм日
Posts

Follow

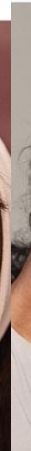

П $\odot \odot \nabla$

391 likes

duckcosmetics $A$ bold gold is next in line. Can you guess what the third variant of Glow Doe is called

Figure 3. Duck Cosmetics Ads DUCKCOSMETICS
Posts

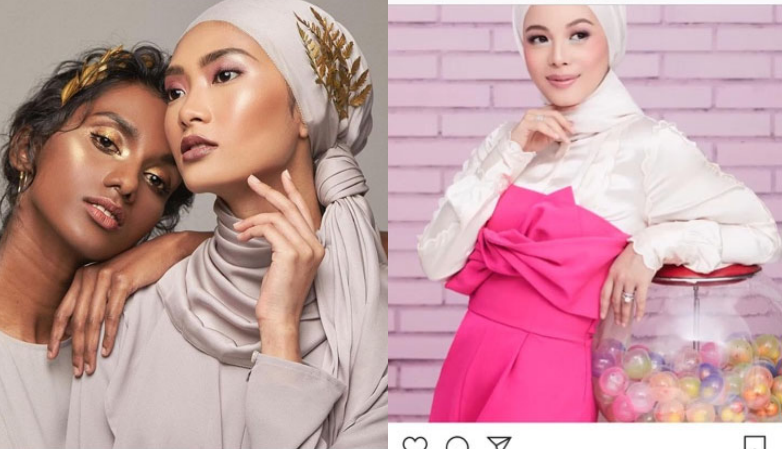

ฤ

duckcosmetics Are you my Candy Girl? If you are, mauve shade of Triple Treat heels for this dusty sweet. Tag a Candy Girl in the comments! $\$$ - D. 
Table 3. Coding of Visual Element in Malaysia Advertisement

\begin{tabular}{|c|c|c|c|c|c|}
\hline No. & Criteria & Description & Ad 1 & Ad 2 & Ad 3 \\
\hline 1. & The Mood & $\begin{array}{l}\text { Feelings that stimulates } \\
\text { the audience }\end{array}$ & $\begin{array}{l}\text { Elegant } \\
\text { romantic }\end{array}$ & Glamorous & Fun and feminine \\
\hline \multirow[t]{2}{*}{2.} & \multirow[t]{2}{*}{$\begin{array}{l}\text { The } \\
\text { Design }\end{array}$} & $\begin{array}{l}\text { 1. Style of } \\
\text { Photograph }\end{array}$ & $\begin{array}{l}\text { Close } \\
\text { portrait. }\end{array}$ & $\begin{array}{l}\text { Medium close up } \\
\text { portrait. }\end{array}$ & $\begin{array}{l}\text { Medium shot } \\
\text { portrait. }\end{array}$ \\
\hline & & $\begin{array}{l}\text { 2. } \begin{array}{l}\text { Colour scheme of } \\
\text { photograph }\end{array} \\
\text { fot }\end{array}$ & $\begin{array}{l}\text { Warm colour } \\
\text { tone. }\end{array}$ & $\begin{array}{l}\text { Warm colour } \\
\text { tone. }\end{array}$ & Pastel colour tone. \\
\hline \multirow[t]{2}{*}{3.} & \multirow{2}{*}{$\begin{array}{l}\text { The } \\
\text { Context } \\
\text { and } \\
\text { Content }\end{array}$} & $\begin{array}{l}\text { Language use in } \\
\text { the advertisement }\end{array}$ & $\begin{array}{l}\text { English } \\
\text { language. }\end{array}$ & English language. & English language. \\
\hline & & Caption purpose & $\begin{array}{l}\text { Persuade people } \\
\text { to buy Duck } \\
\text { Cosmetics } \\
\text { product to get } \\
\text { amazing look. }\end{array}$ & $\begin{array}{l}\text { Informing people } \\
\text { of new product } \\
\text { launching. }\end{array}$ & $\begin{array}{l}\text { Convince people } \\
\text { that the product } \\
\text { suitable for } \\
\text { certain style of } \\
\text { certain people. }\end{array}$ \\
\hline \multirow[t]{2}{*}{4.} & \multirow{2}{*}{$\begin{array}{l}\text { The } \\
\text { Visual } \\
\text { Sign of } \\
\text { Beauty } \\
\text { (face) }\end{array}$} & $\begin{array}{l}\text { 1. The race of } \\
\text { people in the } \\
\text { advertisement }\end{array}$ & $\begin{array}{l}\text { Malaysian with } \\
\text { India type of } \\
\text { face. }\end{array}$ & $\begin{array}{l}\text { Malaysian and } \\
\text { Malaysian with } \\
\text { India type of face. }\end{array}$ & Malaysian. \\
\hline & & $\begin{array}{l}\text { 2. Style of makeup } \\
\text { and hair }\end{array}$ & $\begin{array}{l}\text { Romantic style } \\
\text { makeup and hair. }\end{array}$ & $\begin{array}{l}\text { Glam style of } \\
\text { makeup and hair. }\end{array}$ & $\begin{array}{l}\text { Pastel style of } \\
\text { makeup and hair. }\end{array}$ \\
\hline \multirow[t]{2}{*}{5.} & \multirow{2}{*}{$\begin{array}{l}\text { The } \\
\text { Visual } \\
\text { Sign of } \\
\text { Beauty } \\
\text { (body) }\end{array}$} & $\begin{array}{l}\text { 1. Body shape of } \\
\text { people in the } \\
\text { advertisement }\end{array}$ & Not available. & Not available. & Slim. \\
\hline & & $\begin{array}{ll}\text { 2. } & \begin{array}{l}\text { Fashion } \\
\text { accessories }\end{array}\end{array}$ and & $\begin{array}{lr}\text { Hair band } & \text { and } \\
\text { pearl } & \text { stud } \\
\text { earring. } & \end{array}$ & $\begin{array}{l}\text { Greyish satin } \\
\text { cloth and hijab, } \\
\text { gold }\end{array} \begin{array}{l}\text { hair } \\
\text { accessories, and } \\
\text { hoop earring. }\end{array}$ & $\begin{array}{l}\text { White long sleeve } \\
\text { with pink tube top } \\
\text { jumpsuit, silver } \\
\text { rings, and white } \\
\text { hijab. }\end{array}$ \\
\hline
\end{tabular}

\section{Result and Discussion}

\subsection{Indonesia Brand Advertisement Analysis}

Looking from the visual markings contained in ad 1, the clothes and accessories used by the advertisement models are clothes that are commonly worn during formal events. This is reinforced by the visual mark of the model with neatly arranged hair using hair accessories and using makeup to indicate that the model depicts the atmosphere of how to dress when attending formal events. A bunch of flowers that are held by a model is commonly seen during weddings. Clothing, make up, to other attributes used in advertisements as if describing the atmosphere that usually occurs during weddings. Further seen at visual signs in ad 1, the model used in the ad has a face that has an oriental type of face characteristic, which is white and has a mono eyelid. The makeup on this model also resembles identical K-beauty makeup with a glowing skin look, natural lashes without fake lashes (thin lashes look), shiny pink eyeshadow, and lip gradation (gradient lip look). This visual depiction is certainly not a general description of the types of characteristics of Indonesian women who are generally exotic skinned with double eyelid eyelids. Another sign that is seen completing the advertisement is the written caption "The romantic look with Rollover Reaction's Touch". This caption is interpreted as if the look in the advertisement was achieved because of Rollover Reaction products.

In the second advertisement the clothes and accessories used by the advertisement models are clothes that look chic and elegant. The clothes seemed to strengthen the personality of the model that still looks beautiful even with simple makeup. The impression is then supported again by the warm color atmosphere in the photo as if it reinforces the impression of an adult and elegant. The model used in the second advertisement is a model with a strong exotic impression, seen from the skin color of the model which is medium warm skin tone. This ad is adapting K-beauty (the fuller look lips) by choosing a dark warm tone red lipstick used on the model to adjust the skin color of an exotic model. While on the face, the skin makeup of the model looks naturally healthy. The visual mark of a thin lash look is also seen in the ad 2 models. The model does not use fake lashes on the makeup, eyelashes look naturally curved. This visual portrayal is certainly closer to the general description of Indonesian women who have exotic skin. The advertisement seems to show that the latest trends can also be applied to the type of model as in the ad with the right color selection. The text that is seen completing the advertisement is a caption that says "channel the sunset's gleaming glow with dusk". The caption on the second advertisement suggests that their product can make the face of the model reflect the glitter of dusk, per the name of their lipstick product, Senja (dusk). 
Different from advertisements 1 and 2, in the third ad there are photos of 2 models in front of a nuanced purplish background with light flare photography effects (bokeh). The clothes worn by the two models are not very clear because of the portrait photos angle used in advertisements. Both models were not seen using accessories. Both models use makeup with nude shades with naturally styled hair. The face part of the model, namely the cheekbones, forehead, and shoulders look glowing. Under the photo there is a caption that reads "Let the stars and moon get jealous of your glow". Nude style makeup but glowing (glass skin look) appear on both models. Both models pose back to back by showing the sides of their faces to show the glow of makeup they wear. The glowing makeup is supported by the reflection of light flares on the photo background. The use of 2 models that have different visual characteristics in one photo as if to convey the message that the look display as in advertising can be applied to various types of faces and skin colors. Makeup appearance as in the ad also seems to be able to make the model still looking amazing even without any fancy clothes or accessories. This message is also reinforced by the caption text which states that even the star and moon get jealous of the glow that the model has. As if reinforcing the notion that the quality of the products they use in advertising can be even more glowing than the moon and stars.

\subsection{Malaysian Brand Advertisement Analysis}

Looking from the visual signs contained in advertisement 1 , the accessories and background used by the advertisement look elegant yet romantic. The warm color atmosphere in the photo supported the impression too. The model used in the second advertisement is a model with a strong exotic impression, seen from the skin color of the model which is medium warm skin tone. The model is Malaysian with India type of face which commonly found in Malaysia as we know Malaysia has citizens from various races. The impression of K-beauty on Ad 1 is not very visible. If you look further, Ad 1 would like to show the application of makeup that fits on the model which has a strong exotic impression. The application of K-beauty is only seen on the lip makeup (The fuller look lips) that uses cool pink color to strengthen the feminine impression. The text that is seen completing the advertisement is a caption that says "You can never go wrong with a sweet pink. Matte Love in Pink Crush is the show-stopper your lips need!". The caption seemed to reinforce the notion that the pink color on the lips of the model was strong enough to be the center of attention.

The photo on Ad 2 presents a formal and glamorous impression when viewed from the way of dress and makeup worn by both models. Looking from the visual sign on Ad 2, both models have a strong exotic impression. This is indicated by the first visual model that has a strong Indian face with a medium dark warm skin tone, and a second model that has a Malay face with a medium warm skin tone. Both models face each other in a sideways position to show their glowing faces in the cheekbones (glass skin look). Both models also do not use false lashes (thin lash look). When viewed from the caption written at the bottom of the photo, which is "A bold gold is next in line. Can you guess what the third variant of Glow Doe is called? - D", this ad aims to promote new products that have not been sold yet. This then becomes in line with the use of models that have different skin colors and ways of dressing to show that the new product is suitable for a variety of skin types.

Different from Ad 1 and Ad 2, Ad 3 presents a fun impression. Evidenced by the selection of background colors, clothing worn on models, and photo properties that resemble a Gatcha vending machine. The model is seen leaning on a vending machine containing objects resembling candy-filled balls. This visualization seems to be in line with the caption under the photo "Are you my Candy Girl? If you are, you'll definitely fall head over heels for this dusty want to shade the Triple Treat that's as sassy as it is sweet. Tag a Candy Girl in the comments! - D ". Also, the model uses makeup with colorful shades, which are pastel-colored eyeshadow, pink flush blush, and glossy pink lips. The model's facial skin looks naturally healthy without excessive luster. The model on Ad 3 has a Malay type of face but with a light skin tone. The model also wearing hijab to strengthen the characteristics of Malay Malaysian women who usually wear hijab, although Ad 3 carries fun theme but this advertisement also combining local culture element into the concept.

\section{Conclusion}

In the opinion of Gillian Dyer, Torben Vestergaard and Judith Williamson, it can be seen that there are something special about an advertisement, which differentiates semiotic advertisements from other objects, namely that an advertisement always contains sign elements in the form of the object being advertised. ; context (context) in the form of environment, people or other creatures that give meaning to objects; and text (in the form of writing) that reinforces meaning (anchoring) (Piliang, 2004). It is important to remember that advertising is a communication tool between ad makers and the intended people (users, viewers, observers, readers). The signs contained in advertisements are the language that is intended to be conveyed to its users. The user (interpretant) uses the source of knowledge contained in his environment has its own way to read or interpret a message. In other to reaches its users, the creator of the message (advertising) will use the source of knowledge that is around the user or that is common around the user (audience) for making the message so that it can be understood by its audience. This is also evident in the sample of research objects discussed in the previous 
chapter, namely local brand advertisements from each country that have their own way of applying the 2019/2020 K-beauty trend. Although in history Indonesia and Malaysia are close relatives (kin), in their development the two countries have their own perspectives, habits, and local customs. The difference in the application method for K-beauty trends 2019/2020 in Indonesia and Malaysia is clearly seen in the beauty image displayed by local cosmetic brand advertisements in both countries.

When viewed from the advertisements presented by research objects from Indonesia (brand Rollover Reaction), the influence of K-beauty feels dominant. Evidenced by the use of models that visually resemble oriental characteristics, and the use of semi-natural makeup include glowing skin as a visualization of the Korean Glass Skin trend and natural lashes as a visualization of Thin lash look. This proves that Rollover Reaction as a brand is also heavily influenced by K-beauty in its development. To bridge the influence of K-beauty to its users (audience), Rollover Reaction also uses models with strong Indonesian physical characteristics as a companion of models that have oriental characteristics, to messages the audience that the appearance in the ad (beauty style) can also be applied to audiences who have Indonesian physical characteristics by choosing the right colours and applications. These applications include the selection of warmer colour tones makeup and also the use of highlighter as a visualization of an artificial Glass Skin look, which in reality Glass Skin look is not suitable for Indonesia's tropical climate. Different from Indonesian advertisements, Malaysian local brand advertisements (Duck Cosmetics) lift a strong local impression. Evidenced by the selection of models that have strong local physical characteristics, including models with Malay characteristics and models with Indian characteristics (which are commonly found in Malaysia). Although the influence of K-beauty is seen in the appearance of the ad model, Duck Cosmetics immediately visualizes it to the model that has local physical characteristics (an example can be seen clearly in Ad 2 Malaysia). The visualizations are the choice of warm tones makeup, using a highlighter as an artificial Glass Skin Look which is also in reality not suitable for Malaysian climate (tropical and humid). Duck Cosmetics is also seen displaying visualizations of modern Muslim women in its advertisements. As is well known that Malaysia is a country with a majority of Muslim citizens. Duck Cosmetics raised the theme to give a message to its audience that the look can also be used by Muslim women that wear a hijab. Apart from different perspectives of each country, it can be concluded that local culture in Indonesia and Malaysia still has a strong influence. It was proven from the absence of visual signs that meant local culture in advertisements affected by K-beauty trends. John Fiske emphasized that the media not only presents certain representations of reality but also the media influence and produce the reality that they provide (2004: 1). This sentence from John Fiske seems to be illustrated on how the research objects trying to represent local beauty and also actually directing and influencing the audience to understand that the ideology of K- beauty is the current trend and adapting it to local beauty is a common thing to do.

\subsection{Suggestion}

Based on the results of this research it was found that the method of cultural acculturation in popular local cosmetic brand advertisements was applied both in Indonesia and Malaysia even though done differently. However, researchers cannot conclude that this method will produce the same effect if applied to product advertisements other than fashion products. Need further study on whether a similar method can be applied to product advertising other than fashion products. Also, researchers cannot conclude that this cultural acculturation method can be applied if the trend comes from Western culture. There is a possibility that this method was successfully carried out due to the influence of Asian allied culture. Further research is needed to prove that similar methods can be carried out if these trends originate from western culture. The brand samples selected in this research are in the start-up company category, so researchers recommend further research to reach larger local brands to get a broader perception.

\section{References}

Arsitowati, Winta, H. (2018). Kecantikan Wanita Korea Sebagai Konsep Kecantikan Ideal Dalam Iklan New Pond'S White Beauty: What Our Brand Ambassadors Are Saying. Humanika, 24(2), 84-97. https://doi.org/10.14710/humanika.v24i2.17572

Albeman Devon. (2019). These Are the Biggest Makeup Trends in South Korea in 2019. Allure.com.

Barnard, M. (2006). Fashion Sebagai Komunikasi: Cara Mengomunikasikan Identitas Sosial, Seksual, Kelas, dan Gender. Yogyakarta: Jalasutra.

Barthes. (1977). Image Music Text. (Essays selected and translated by Stepehen Heath). London: Fontana Press. Bee Shapiro. (2019). Everyone Is Crazy for Glass Skin. Here's How to Get the Look. nytimes.com.

Belova, O. (2006). Speaking for Themselves? Problematising the Production of Meaning in Visual Artefacts. Culture and Organization, 12(1), 37-49.

Chaubey D.S, Sharma Jyoti. (2010). Body Image in Advertising and Emerging Fashion Trend. Omkarananda Institute of Management and Technology.

Choi, Eunji. (2018). Korean Fashion Media, Beauty Ideals, and Colorism: Examining the Prominence of 
Whiteness between 2013 and 2017 in CÃf ÂCCi Magazine. pp. 6-7., doi:10.31274/etd-180810-5961.

Cloris Li. (2019). Korean Beauty Standard : what is it (female beauty standard), related cosmetic surgery and problems this standard caused. https://storymaps.arcgis.com/).

Culler, Jonathan. (2001). Barthes, A Very Short Introduction. New York: Oxford.

Dwityanti, Esthi. (2008). Analisis Faktor-Faktor Yang Mempengaruhi Minat Beli Konsumen Tehadap Layanan Internet Banking Mandiri (Studi Kasus pada karyawan Departemen Pekerjaan Umum Jakarta), Tesis Universitas Diponegoro, Semarang.

Fiske, John. (2004). Cultural and Coomunication Studies. Sebuah Penganter Paling Komprehensif. Yogyakarta: Jalasutra.

Greg Guest, Kathleen M. MacQueen, Emily E. (2012). Applied Thematic Analysis. SAGE Publication,

Jack Caulfield. (2019). How to do thematic analysis. https://www.scribbr.com/.

Kuntjara, E. H. (2001). Beauty and the Beast: Images of Women in Advertisements. Journal Desain Komunikasi Visual, 3(2), 97-106.

McLuhan, Marshall. (1964). Understanding Media. The Extension of Man. London: Routledge \& Kegan Paul.

Mindy Wright. (2019). 5 Korean fashion Trends Which Are Gaining Popularity Worldwide. ceoworld.biz.

Moira Maguire, Brid Delahunt. (2017). Doing a Thematic Analysis: A Practical, Step-by-Step Guide for Learning and Teaching Scholars. AISHE-J Volume 8, Number 3.

Piliang. (2004). Iklan, Informasi, atau Simulasi?: Konteks Sosial dan Kultural Iklan. MEDIATOR, Vol. 5 No.1 2004. Universitas Islam Bandung.

Piliang. (2004). Semiotika Teks: Sebuah Pendekatan Analisis Teks. MEDIATOR, Vol. 5 No.2.

Russon, Mary-Ann. (2018). K-beauty: The rise of Korean make-up in the West. https://www.bbc.com/.

Sabrina Tiong. (2015). 5 Easy Ways To Get The K-Beauty Gradient Lip. herworld.com.

Sari, W. P. (2015). Konflik Budaya Dalam Konstruksi Kecantikan Wanita Indonesia (Analisis Semiotika Dan Marxist Iklan Pond's White Beauty Versi Gita Gutawa). Jurnal Komunikasi Untar, 7(2), 198-206.

Subadi, Tjipto. (2006). Metode Penelitian Kualitatif. Muhammadiyah University Press. Surakarta.

Tantya Hapsari S. (2017). Model Bisnis Penyelenggara Acara Kelas Merias Make It Organizer. Universitas Gajah Mada.

Tilaar, M. (1999). Kecantikan Perempuan Timur. Magelang: Indonesia Tera.

Vera, Nawiroh. (2014). Semiotika dalam Riset Komunikasi. Bogor : Penerbit Ghalia Indonesia.

Vivian Yeong. (2019). Korean makeup trends 2020: base, eyes, and lips looks to try + new shade you MUST have. https://dailyvanity.sg/.

Wan Roazha Wan Mat, Hyung Jun Kim, Ahmad Azaini Abdul Manaf, Grace Phang Ing, Azaze-Azizi Abdul Adis. (2019). Young Malaysian Consumers' Attitude and Intention to Imitate Korean Celebrity Endorsements. Asian Journal of Business Research Volume 9 Issue 3.

Weng Marc Lim, Ding Hooi Ting. (2011). The Construction of Beauty in Malay Magazine Advertisements. Contemporary Management Research Pages 173-196, Vol. 7, No. 3.

Why Seoul is now Asia's hottest fashion city. (2017). Hypebeast. 